\title{
Narrating Palaeolithic Human Settlement History : the case of the Imjin-Hantan River Area, Korea*
}

Yongwook Yoo**

\section{Introduction}

In the Imjin-Hantan River Area (the IHRA hereafter, 臨津-漢灘江 流域) in the midwestern region of the Korean Peninsula there are more than a dozen Palaeolithic sites. This region is renowned for the discovery of Acheulian-like handaxes at the Chŏngongni (全谷里) site in 1978 (Kim and Chung 1979). Since then, other neighboring sites have yielded over 100 specimens of handaxes, leading many international researchers to recognize this area as one of the most fruitful Paleolithic regions in East Asia in terms of handaxes.

Several excavations and regional geoarchaeological research have been continuously proposing many important issues in the context of hominid's ${ }^{1}$ occupation history at the far eastern margin of the Eurasian continent. Among these issues, the significance of the handaxe still remains questionable because this region is within the "chopper-chopping tool"

* This work was supported by the National Research Foundation of Korea Grant funded by the Korean Government (NRF-2012S1A5A8022156).

** Assistant Professor, Department of Archaeology, Ch'ungnam National University

1 In this text, "hominid" refers to the entity of ancient humans including extinct species before modern Homo sapiens (Klein 2001). 
area, the zone of Pleistocene cultural/technological "retardedness," as suggested by Movius (1944). ${ }^{2}$ Although many attempts have been made to elucidate the meaning of this culturally unique lithic assemblage, some inherent difficulty in interpreting the geological sequence of the later Pleistocene (ca 0.7- 0.12 MYA) period hindered researchers from acquiring a conclusive chronology.

With new publications of chronometric dates and several unprecedented archaeological discoveries-e.g. Chŏngongni, Changsanni (長山里), Chuwŏlli (舟月里), Kawŏlli (佳月里), Kŭmp'ari (金波里), Hwadaeri (禾岱 里), and Changhŭngri (長興里) - from 2000 to 2006, we can have a new temporal framework on the IHRA lithic assemblage. In short, the formation of the IHRA lithic assemblage was, according to recently acquired geochronological dates, initiated no earlier than MIS $6,{ }^{3}$ and the variability of the IHRA assemblage witnessed a detectable temporal change until MIS 2 where the final stage of the Palaeolithic era persisted until the onset of Holocene (ca $10 \mathrm{kya})^{4}$; this long duration is identical to the Middle and Upper Palaeolithic ${ }^{5}$ periods in the western hemisphere. What is im-

2 In the early twentieth century, Hallam L. Movius, then a professor of anthropology at Harvard, proposed that the Palaeolithic Old World can be divided into two domains based on the presence of the handaxe. He even assumed that the East Asian "Chopper-chopping tool" zone, which has no evidence of the typical Acheulian handaxe, is attributed to the culturally retarded habit of ancient Asian races (Movius 1944).

3 MIS is an acronym of Marine Isotope Stage, and its number demonstrates the relatively warm and cold phase of the Pleistocene glacial period. In general, the odd numbers indicate warmer period while even numbers indicate the colder period. The MIS is alternatively replaced with Oxygen Isotope Stage (OIS) because the ratio of oxygen isotopes $\left({ }^{16} \mathrm{O},{ }^{17} \mathrm{O},{ }^{18} \mathrm{O}\right)$ in the geological sediment is used for determining the climate condition under which the sediment was accumulated.

4 The "kya" is a geochronological term that equals to one thousand years ago and "mya" to one million years ago. These two terms are commonly used acronyms in the fields of geology and archaeology.

5 The Middle Palaeolithic period (ca from 200 to 40 kya; see Gao and Norton 2001) is generally accepted as a period of Neanderthals in Europe and Western Asia, and 
portant about this chronological bracket is that we need to explain the geological process using the environmental background of this area; and we must associate this process with the mode of hominid occupation in an appropriate manner.

As an attempt to infuse the current discussion with a broader perspective, this article is intended to describe the history of human occupation in this area. The first section of this article introduces the IHRA and its archaeological features: its geological landscape, important sites, and the diversity of lithic assemblages discovered in the IHRA. Based on these basic data, the second section will discuss the theoretical background of long-term-based changes in the archaeological record from a historical context; this task will incorporate the speculation of environmental change in connection with human behavior. Ferdinand Braudel's concept of "la longue durée" will be archaeologically examined to build a narrative on the history of hominid occupation, and the general process of river channel system development will be demonstrated as a principal agent responsible for the environmental background of the IHRA. The third section will describe hominid actions reflected in the archaeological record in the tempo with landscape changes in this area. Six phases of geological events will become the units for diachronically associating hominid land-use pattern with environmental change. This will be an attempt to demarcate the changing mode of hominid survival strategy in this area, and provide an explanation for how and why current archaeological data geographically and temporally appear unique.

the Upper Palaeolithic period (ca from 40 to $10 \mathrm{kya}$ ) is when anatomically modern humans (Homo sapiens) globally replaced former hominids such as Neanderthals (Europe) and Homo erectus (Asia). 


\section{The Palaeolithic Archaeological Record in the IHRA}

\section{Geographical Settings}

The IHRA straddles the De-Militarized Zone (DMZ) between North and South Korea, and lies largely in the district of Kyŏnggi Province, with a portion in Kangworn Province to the east. ${ }^{6}$ The Imjin River, the largest fluvial channel of this area, runs through the IHRA from the southernmost part of North Korea. The Hant'an River, one of the largest tributaries of the Imjin River, originates in the northeastern part of the IHRA near Ch'ŏlwŏn County and merges with the Imjin River near its center (Fig. 1). These two river channels form the main fluvial drainage system within the Ch'ugaryŏng Rift Valley (the CRV hereafter), and are principal factors responsible for the current landscape of the IHRA.

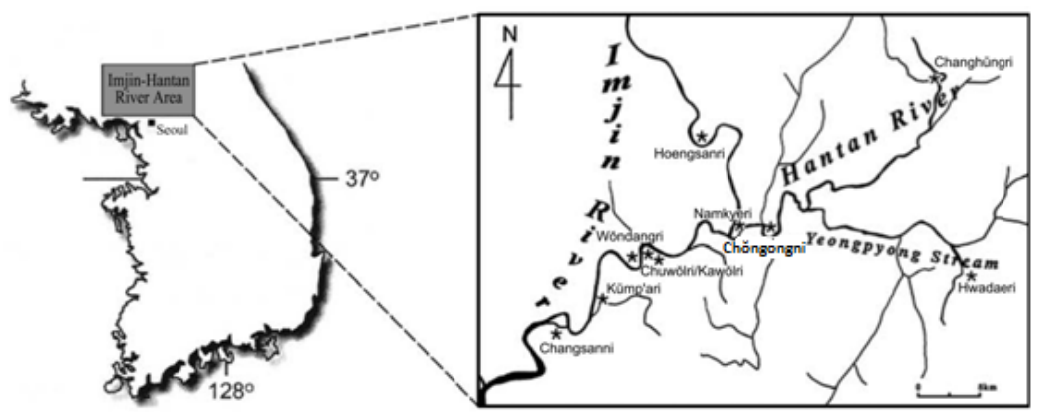

Figure 1. The location of the IHRA and major Palaeolithic sites around the Imjin and Hant'an Rivers

The CRV crosses the Korean Peninsula from the northwest of Seoul to Wŏnsan City on the eastern coast. The lower stratigraphic unit of the $\mathrm{CRV}$ is composed of Precambrian banded gneiss, partly intruded by

6 The GPS of the IHRA is approximately $37^{\circ} 35^{\prime}$ to $38^{\circ} 15^{\prime}$ latitude, and from approximately $126^{\circ} 30^{\prime}$ to $127^{\circ} 20^{\prime}$ longitude. 


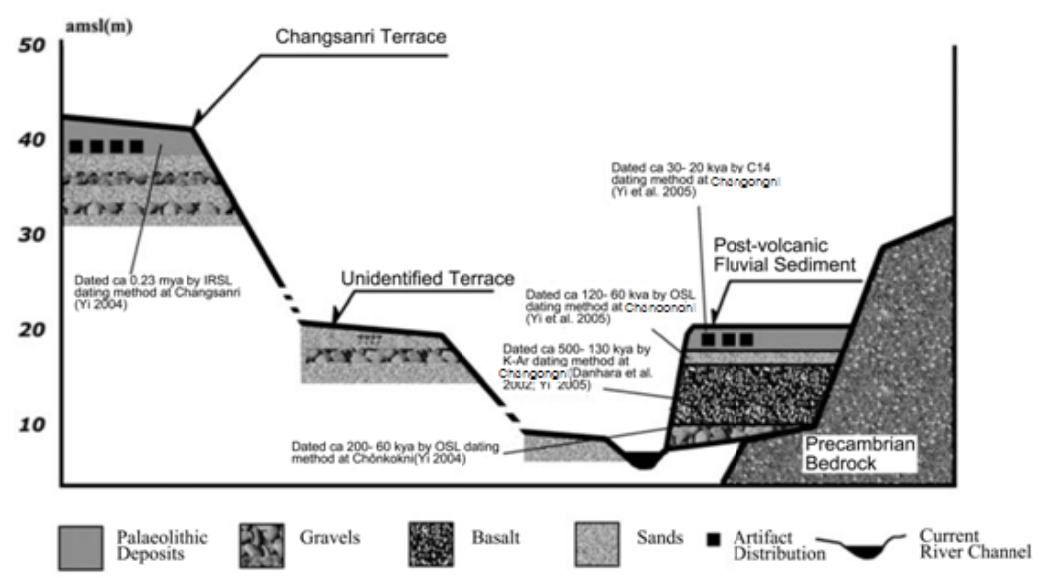

Figure 2. Schematic cross-section of the IHRA geological units and relevant dates

gabbros around 1000 mya (Kim and Lee 1994). Above this Precambrian bedrock is a series of gravel and sand layers, which comprises the Paeküiri Formation. The Paekŭiri Formation consists primarily of quartzite, gneiss and granite, all of which originated from the Precambrian bedrock below (Bae 1988), and is believed to have been formed by the erosion of strongly flowing streams, especially in the midstream area of the Hant'an River.

As can be seen in Fig. 2, the exact correlation of the chronometric dates is difficult to ascertain because the sequence of strata is different from location to location. The general features of the IHRA can be characterized by the formation of thick basalt that is the result of lava flow dated Middle Pleistocene; this lava flow is concentrated in the upper and middle region of the Imjin River, but not well-represented in the lower part such as Kŭmp'ari, Chuwŏlli, and Kawŏlli sites. Thus, it can be assessed that the geological contexts in the entire area are far from the result of uniform and simultaneous formation processes, and the dating of the IHRA lithic assemblages cannot be solely dependent on the age of basalt layer contrary to previous opinions (e.g. Norton et al. 2006; Bae et al. 2006). 
Archaeological Remains and their Chronological Range

The IHRA yields various lithic assemblages with diversity in morphology and in manufacturing procedures of tool types. Handaxes from this region are appropriately finished and their thickness is notably greater than that of typical Acheulian implements; the reduction sequence ${ }^{7}$ is simple and the blanks are casually modified without being shaped to their perfection. At least three-unifacial, bifacial, and alternate shapingmanufacturing methods for producing handaxes were prevalent in the IHRA assemblages and each method is sufficiently effective to obtain workable lateral edges and a useful pointed tip at its distal end (Yoo 1997). Compared to a typical Acheulian handaxe, it might have been produced with an underdeveloped technique and the IHRA hominids probably exert less effort to perform intensive reduction for shaping (Yoo 2008).

The age of the IHRA handaxe has been a significant issue for decades. While no indisputable handaxe was found in situ at Changsanri, a large pointed tool indicates that the beginnings of handaxe manufacturing were imminent when hominids first resided in this area (1 of Fig. 3). Notwithstanding that the real age is possibly older, the current available IRSL date of the Changsanri Terrace is ca 0.23 mya (Yi 2004). It would be, therefore, unpresumptuous to take this date as a provisional lower limit age of the IHRA handaxe. The upper limit age can be indicated by the example of a sample from Chŏngongni in 2004 (Yi et al. 2006; 2 of Fig. 3). It was discovered in the sediment below the first crack which usually contains Aira-Tanzawa $(\mathrm{AT})^{8}$ tephra; the crack is regarded as evidence of

7 "Reduction sequence" refers to a series of manufacturing tasks performed on a single lithic specimen. Because the original stone gradually reduces as manufacture progresses, its formal trajectory tends to reflect sequential actions and imposed tasks.

8 The Aira-Tanzawa tephra (AT) is chrono-specific volcanic ash particles with the origin of Kyushu, Japan. Its date is solidly measured ca $24-27$ kya by the AMS 
geological features reflecting extremely cold and dry phases of the last glacial cycle, usually dated around 23- 26 kya (MIS 2).
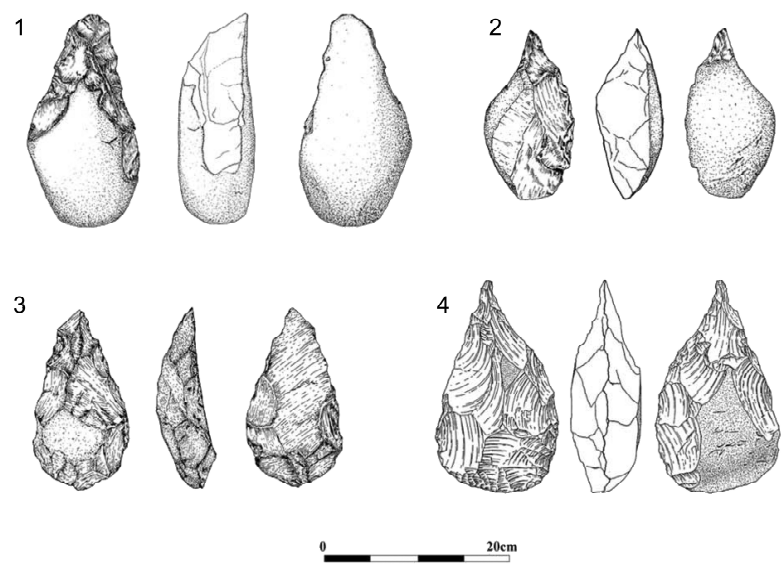

Figure 3. Handaxes discovered in the IHRA (1: Changsanni; 2. Chŏngongni; 3 Chuwŏlli; 4. Kawŏlli)

In addition to the handaxe, a number of small tools made of normal flake, broken shatter, and miscellaneous chips are discovered within the level of MIS 3: for example, in Chŏngongni, Kawŏlli, and Kŭmp'ari, various small tools were found from just below the top crack where AT particles are usually discovered. In this case, it can be assumed that the handaxe and various small tools were simultaneously made for a considerable long time before the MIS 2; and that both the production of handaxes and small tools were in the similar technological context. Considering the low quality of raw materials (quartz and quartzite) and the lower intensity of the techniques performed, we can surmise that the technological level of the IHRA lithic assemblages were constrained by disadvantages in local raw material and by the low need to produce high- 
calibered specialized tools (Yoo 2008).

These apparently crude and pragmatic lithic assemblages show a drastic change approaching MIS 2 . The quartz and quartzite, principally exploited for both large and small tools, became less dominant and new highquality materials such as porphyry and obsidian began to be heavily utilized. Accordingly, the handaxe and other large tools became scarce and several small tools of low quality materials remain in less quantity. The Changhŭngni and Hwadaeri sites which have a good remainder of younger layers above the top crack well-illustrate a transition from low to highquality material assemblage. According to the Hwadaeri excavation results (Choi and Yoo 2005), the size of the quartz tools gradually decrease and new raw materials of rhyolite, porphyry and obsidian emerge around the terminal MIS $3^{9}$. The Changhŭngni assemblage from the top cultural layer is composed of highly modified small tools and of such tiny blanks as heavily utilized chips and microblades. While not found associated in situ, there are also several discoveries of high-quality materials at Chŏngongni (Yi et al. 2006), Kŭmp'ari (Bae et al. 2006), and Heongsanni (Bae et al. 2006). Considering this, it is probable that the low-quality materials were finally replaced by exotic high-quality materials in the entire IHRA around MIS 2; and the manufacturing technique with these highquality materials is on par with the local Upper Palaeolithic tradition, both chronologically and technologically.

The Middle/Upper Palaeolithic transition in the IHRA is not wellknown, but, as far as the transitional phase shown at Hwadaeri and Changhŭngni is taken into consideration, the change into high-quality materials and the "extinction" of the handaxe might have paralleled the emergence of local Upper Palaeolithic technology in this area (Yi 1999; Yoo 2008). This transition could have been instigated either by the arrival of a new hominid population or by the prompt technological adaptation of

9 The date of the Hwadaeri assemblage is $39 \pm 1.4,30 \pm 1.7$ kya by Optically Stimulated Luminescence (OSL) dating before the top crack where Aira-Tanzawa tephra is usually contained (Choi and Yoo 2005: 36). 
indigenous hominids in response to the rapid environmental deterioration around the onset of the MIS 2 (Yoo 2008).

\section{Time and the Evolution of Fluvial System}

Understanding "la longue durée"

Surveyed above, the IHRA lithic assemblage displays a unique but gradually evolving repertoire of lithic technology over a considerable amount of time. The ultimate goal of this article is to explain the process of this long-term technological evolution and to create an appropriate narrative including material evidence and hominid behavior. What is a prerequisite for this goal is a theoretical consideration of the concepts of time, chronology, and the temporal scope of observation (Chazan 1995; Hodder 1987). Braudel's la longue durée can be used as an effective framework for delineating the dynamics of the Pleistocene landscape and the interaction of hominids with their external world.

Ferdinand Braudel (1972, 1980), the champion of the Annales school, scaled time of the past into a "Trinitarian" hierarchical chain of rhythms (Smith 1992: 25; Fletcher 1992: 37): long-term geographic or environmental structures (la longue durée), medium-term socio-political cycles (conjuncture), and short-term socio-political events (l'historie événementielle). In his multi-dimensional time-scale, physical or material factors operating over long periods of time act as constraints on human behavior (Knapp 1992: 6). Unlike environmental determinism, Braudel's approach to the understanding of la longue durée is based on the perspective of "macro-history" as more than human ecology incorporating geological, biological, environmental and social interrelationships. Different from embracing trite events of short duration, la longue durée is not influenced by the pulse of short-term events. Rather it constructs the structure of human relationships along with external constraints, where "constant repetition and ever-recurring cycles" in which "all change is slow" are 
activated (Braudel 1972: 20).

Analogous to this, Butzer (1982), with a clear archaeo-evolutionary perspective, proposed a scheme composed of three modes of adaptation defined in terms of time: 1) the "adaptive adjustments" directed to solve the social and economic problems in the short term; 2) the mediumtermed "adaptive modifications" involving "substantial revision of adaptive strategies within the context of a viable and persistent adaptive system" (Butzer 1982: 290), a mode which is exemplified by the "Upper Palaeolithic Revolution" (Gilman 1984); 3) finally, the long-term "adaptive transformation" realized in the gradual change of technological systems by incorporating a multitude of different adaptive modes (Smith 1992: 25).

While more specific and practical for explaining the dynamics of longterm Pleistocene history, Butzer's scheme puts too much emphasis on environmental stress to address the full range of relationships between human populations and their natural world (Smith 1992). In Butzer's terms, the strategic behaviors of hominids, the active actors responsible for the cultural transformation, are treated as "predestined" by being deterministically regulated by external constraints. Braudel's original longue durée, although not covering the "very remote period" such as the Pleistocene, does not exclude the relevance of intentional forms of human (or hominid) intervention in the natural and social processes that operate at different temporal rhythms. These forms can be technological innovation based on creativity (Hodder 1998; Mitchen 1998), the development of social networking (Mithen 1990; Gamble 1998, 1999), and new forms of information exchange including social learning (McNabb et al. 2004; Mithen 1996).

\section{Landscape and Geological Time-scale}

An interpretation of the IHRA geological processes requires an understanding of the landscape as a "natural background" (Knapp and Ashmore 1999: 5- 8) where a wide variety of cultural and technological activities 
took place. This interpretation begins with an assumption that the principal actors of the IHRA are members of the hominid population who were responsible for the production of lithic assemblages. The landscape was perceptually created by these actors and their practice was structured therein (Giddens 1984: 2; Hopkins and White 2005: 16). While behavior can be understood as the ecological and technological engagement hominids have with their environment, practice is understood as mediated by their cultural knowledge and the know-how performed in terms of social contexts (Gamble and Porr 2005: 8). Hence, as an individual actor, the hominid engages with the natural and social world by behaving through the mediation of the culture, and transforms this engagement with a practice that generates changes in the socio-natural world. In other words, a hominid is enacted within the background of the physical world as its context, actively engages with the natural environment, and this engagement subsequently necessitates further action and reaction.

As has been demonstrated by previous research (e.g. Yi 1996; Yi et al. 2004), it is widely accepted that the IHRA hominids were not new immigrants but indigenous residents in the basin area of the CRV from the later part of the Middle Pleistocene (i.e. ca 0.23 mya, according to the maximum age of the Changsanni Terrace, see Fig. 2). This can lead to a view that the IHRA lithic assemblage was a reflection of structured practices and that these practices had been routinely and "spontaneously repeated" on a daily basis (Hopkins and White 2005: 18). However, these practices should not be treated as "a predestined phase of actions and fates" (Gamble 1993: 19); rather, they were generated by hominids through their ongoing perceptual experiences of the world they occupied.

To trace long-term Pleistocene history in the context of the changing IHRA landscape, the stratigraphic units need to be related to the levels of geological activities along with different time-scales (Chazan 1995). Using the concept of the la longue durée, each of the different time-scales of the IHRA geological processes can be evaluated. It is unequivocal that one of the major components of the IHRA landscape is the Imjin-Hant'an River and the complex history of its channel system can be a conduit for 
the hominid residence and local adaptation. The channel system continuously evolved over time, thereby changing its configuration and drainage. No doubt it was differently perceived by the occupants in that area over these different times. Related to this, Vandenbergh (1995: 632) has stressed three time-scales with respect to the development of the channel system and the relationship between the river dynamics and other accompanying physical factors.

1) One-hundred-thousand year unit (100,000 yrs): The fluvial evolution is climatically contingent and affected by tectonic dynamics. The correlation between glacial/interglacial cycles with changes in the tones of sediment in the Chŏngongni stratigraphy is a typical example of this time-scale (Bae 1988).

2) Ten-thousand year unit (10,000 yrs): The fluvial action is determined by vegetation, soil cohesion and run-offs, while short unstable phases alternate with long periods of inactivity. The correlation of isotope stages and the changes in soil texture and with alternating color bands is based on this time-scale (e.g. Naruse 2003; Yi 2000).

3) One-thousand year unit (1,000 yrs): The fluvial change is dependent upon the intrinsic evolution of the channel system and inundation, as well as other transforming agents. Changes in soil morphology, appearance of surface features and weathering effects within a single stratigraphic unit are based on this time-scale.

Out of these three stepwise time-scale units, the difference between a 100,000 year unit and a 10,000 year unit is the key point of discrepancy among different viewpoints on the formation of fluvial sediments in the IHRA. This is largely due to the confusion on the age of the IHRA assemblages interpreted with the chronometric dates because the resolutions of the applied dating techniques are very low and interpretations of the geological formation processes tend to hinge on the different time scales these dates are calculated from. In order to have hominid occupation history narrated on a more accurate level, the 1,000 year time-scale unit 
needs to be applied to clarify the evolution of the Imjin-Hant'an River channel system as well as the practices of hominids. This time-scale will enable us to connect the intrinsic evolution of the channel system to the transformation of the river bank area and to the drainage configuration; the hominid occupation will be meaningfully positioned and its adaptive strategy explored on the basis of available archaeological data.

\section{Evolution of the Channel Systems in the IHRA}

The evolution of a channel system is a time-dependent function of hydraulic dynamics and a circulating process of non-reversible change (Brown 1999: 76). The fluvial channel tends to maintain its stability to the degree that the discharging flow is balanced with the incoming flow, and this tendency toward stability is termed "channel equilibrium" (Rapp and Hill 1997). If this equilibrium is broken, the channel current rapidly reacts by eroding and flooding until the original stable status is recovered. Brown (1999: 24) demonstrates this process with special reference to different channel configurations and changing mechanics (Fig. 4). Based on the hydraulic forces and the morphology of diverging channels, his model summarizes four stages of channel evolution: 1) braided, 2) anastomosing, 3) tri/bi channel and 4) single channel. Since the Imjin-Hant'an River system can be considered a normal fluvial channel, a catastrophic interception of lava flow will force it to undergo all four stages of Brown's model. This is because the huge lava dam blocked the ancient channel, forcing the initiation of the process as if it were a new channel.

The channel-system-based landscape is a basis for understanding how the individual hominids selectively cognized the external world as a principal water-supply source and habitat for exploitable plant and animal resources, as well as being a possible route for traveling beyond the territorial limits of their everyday provisioning tasks (Vandenburgh 1995). The general process of geomorphological transformation and the consequential impact on hominid perception of the landscape will be examined using both the 10,000 and 1,000 time-scale units. The next section is a 


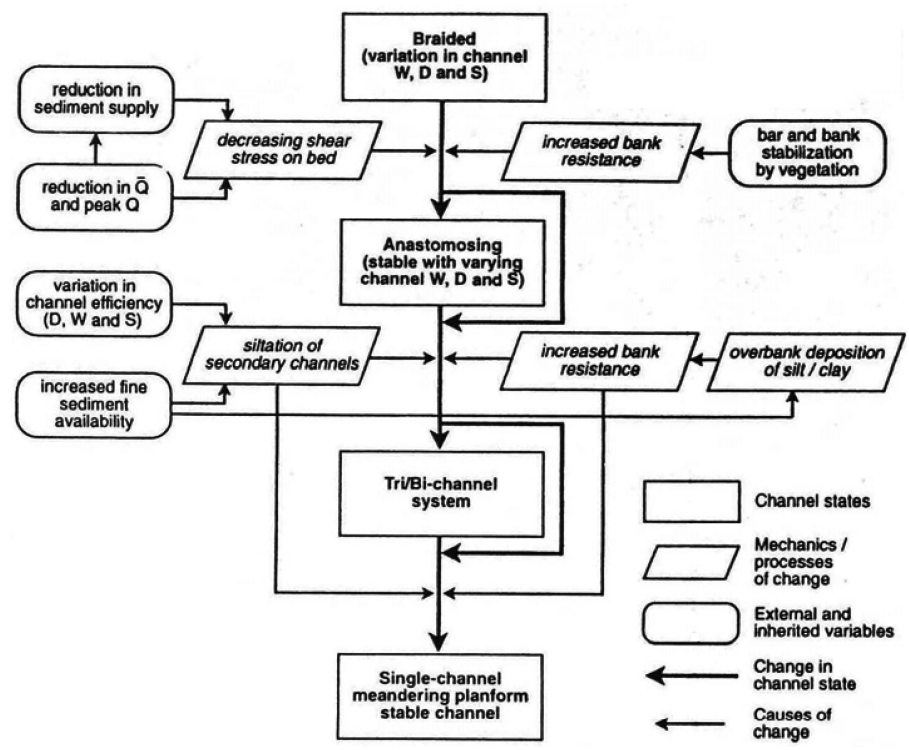

Figure 4. Flowchart of fluvial channel evolution and its factors based on Brown (1999: 24)

narrative on hominid practices in the context of the natural environment and the mediation of their survival strategies. This narrative is based on the six-phased schematic change of the landscape in the IHRA. This sequence of phases includes 1) the pre-volcanic phase, 2) the lava flow phase, 3) the initial braided stream phase, 4) the intermediate anastomosing system phase, 5) the single channel down-cutting phase, and 6) the final stabilized phase.

\section{Six Phases of the Geological Process in the IHRA}

Phase 1: the pre-volcanic phase (before ca 0.20 mya)

The original terrain of the CRV was very rugged and uneven. The ancient river channel developed across this narrow valley and its channel 
configuration was determined by multidirectional troughs of the CRV. As water descended along the steep gradient of the troughs, its velocity became rapid. The main stream channel was continuously cut down toward the bottom, and the trough expanded to maintain the equilibrium in its current of flow discharge (Rapp and Hill 1997). The high-velocity of the water flow through the channel transported boulders and organic debris from the hillside, generating much frictional drag. When the velocity of water decreased, a thick deposit of cobbles and gravels (e.g. the Paekŭiri Formation) accumulated on both sides of the channel. A stepwise series of river terrace surfaces developed as a result of the fluctuation of channel surface and/or of the tectonic upheavals of the river bed (the left section of Fig. 2 and Fig. 5).

\section{Phase 1}

\section{Before ca 0.20 mya}

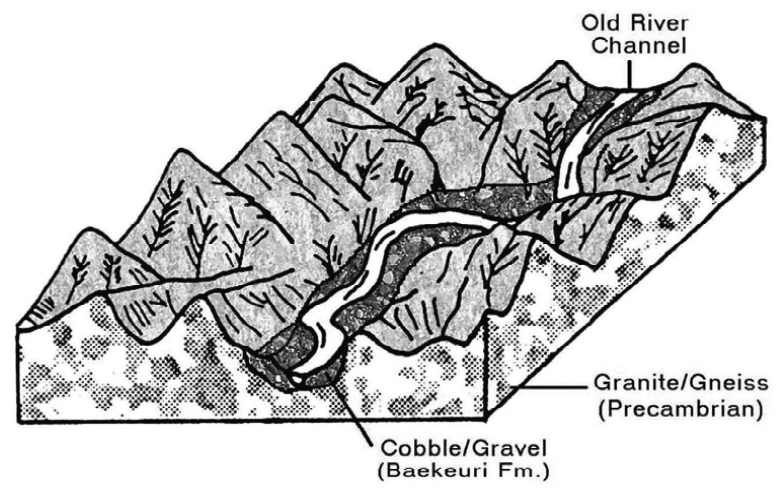

Figure 5. Illustration of Phase 1

The hominid occupation seems to be minimal during this phase. Only the Changsanni Terrace surface preserves a handful of lithic artifacts, and other locations do not have any in situ artifact concentrations. The upper region of the Imjin River shows a similar river terrace sequence (Yi 2004; Yi et al. 2004) but currently no unequivocal evidence of hominid residency has been reported. The altitude of the Changsanni site makes it an ex- 
cellent vantage point for viewing the entire shore area of the Imjin River. The density of artifact distribution and the intensity of raw material utilization appear to be very limited. This indicates that the frequency of site formation was extremely low. Therefore, interaction among local hominids was probably scarce.

The Changsanni hominids did not have any cognized standard for selectively identifying the properties of rock types. As a result, the diversity of assemblage variation was extremely low and the raw material utilization was entirely based on the memory of previously "fractured" nodules; they could have barely specified what sizes and what forms of cortex on cobbles/pebbles would have made them worth targeting for the next fracture.

Phase 2: the lava flow phase (ca 0.2- 0.13 mya)

The accumulation of clastic cobble and gravel deposits was covered by a huge lava flow blocking the old river channel. The estimated age of the lava flow, according to the several K-Ar dates and the sequence of OSL dates summarized earlier (Fig. 2), is about 200- 130 kya. The number of lava flows was probably more than one, but the exact number is still unknown (Yi 2005). After the volcanic activity terminated, the lava cooled and solidified into the basalt formation. All exposed archaeological evidence, if any, was incinerated and, in any case, it was totally overlain by this basalt. The morphology of the lava flow was determined by the very irregularity of the existing terrain at that time, and by the rapid cooling process caused by the channel water. As a result, the surface of cooled lava flow became very irregular and randomly uneven.

Hominid occupation was only possible beyond the margin of the lava flow; the Changsanni area still probably was occupied while the middle and upper region of the valley was subjected to the volcanic "bombardment." Because a vast area of the IHRA was overtaken by lava, hominid residential shelters were probably located at more elevated levels; hominids were forced to move to the forested uphill zone from the lowland and 
also spread to the region of the upper CRV. The direction of population migration was likely influenced by the scattered distribution of water sources left by the differential cooling of the lava flow.

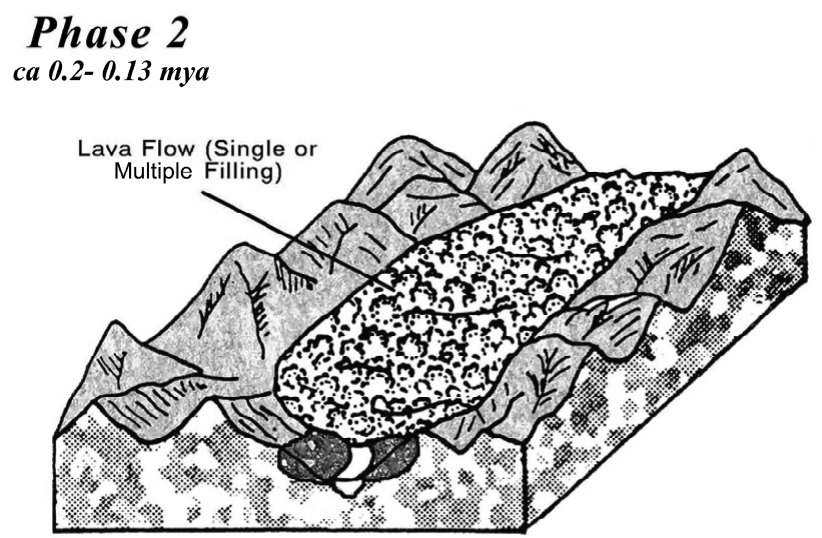

Figure 6. Illustration of Phase 2

It can be hypothesized that major landscape changes stimulated new task-oriented strategies to emerge, including the development of systematic tool procurement technology. The production of durable lithic tools became more efficient and this type of technological adaptation was repetitively practiced. However, the need to locate residential shelters in the highland area is extremely disadvantageous because the daily cycle of descending and ascending the hills, both for procuring lithic raw material and for foraging under conditions of resource instability, caused high energy costs. As a result, finding evidence contemporaneous with the lava flow of regular hominid occupation sites in the landscape is highly problematic.

Phase 3: the initial braided stream phase (ca 130- 120 kya)

Since the old channel system was mostly covered and the new riverbed 
was elevated by cooled lava, a steeper gradient might have accelerated erosion actions. The main channel became dissected into numerous small branches and each separate branch channel had no fixed drainage configuration because it randomly flowed over the basalt (Fig. 7).

The increased net sum energy in this wider channel system on the elevated riverbed produced vigorous turbulent flows. As a result, a highcharged braided system of channels filled by rapid and turbulent water developed and this caused significant lateral cutting of the basalt surface. Large-sized debris from the basalt was transported in a saltation movement through rapid drainage. The indenting actions of these turbulent surface flows started to carry out a new channel configuration and some pockets of locked water, formed in the depression of the uneven basalt bed, subsequently developed into ephemeral swamps.

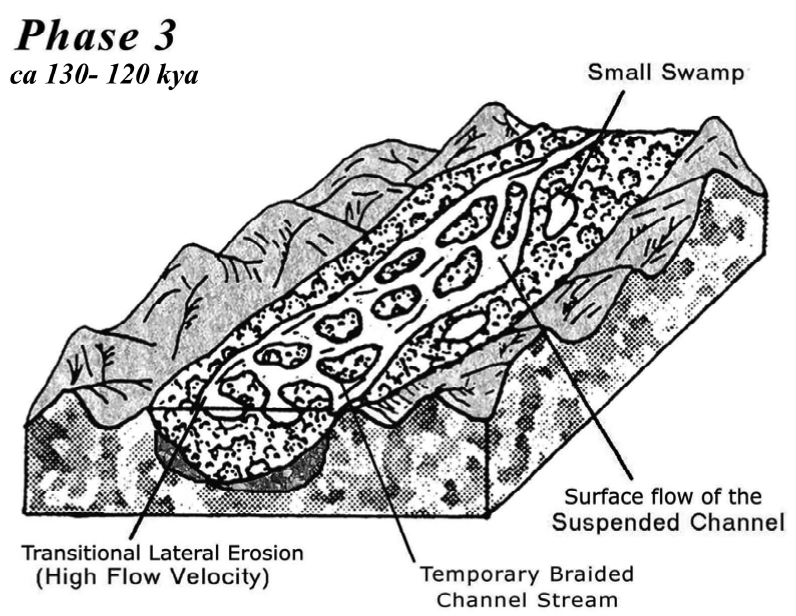

Figure 7. Illustration of Phase 3

The length of this phase was determined by the OSL dates of the samples from the bottom of the coarse sand layer at the Chŏngongni site (see also Fig. 2). Archaeological evidence is very scarce from this phase. Although the vicinity of the river channel was fairly beneficial to hominids, 
the drainage flow was very strong and randomly directed channels generated extremely unfavorable conditions for preserving artifacts and fossil remains. The terminal region of lava flow in the lower Imjin River, including the Chuwŏlli, the Kawŏlli and the Kŭmp'ari sites, was probably under relatively more favorable environmental conditions than other locations since a small amount of lava flow could have made some areas habitable. As a result, a group and/or several groups of hominids became concentrated around such well-positioned locations as the Chuwŏlli and the Kawŏlli sites where overall distribution of resources from the riverside and the woodlands was consistent. Within this area, some raw materials were newly encountered and became more actively utilized while an elementary ability of selective procurement developed among the hominid groups. The mechanism of basic lithic fracture was noticed, memorized, and socially incorporated, and transmitted. ${ }^{10}$ However, strongly supportive archaeological evidence is not guaranteed since hominid practices of tool manufacture were still rudimentary, and apparently failed to formulate any patterned remains.

Phase 4: the intermediate anastromosing system phase (ca 120- 60 kya)

As a result of lateral cutting, the braided streams gradually merged and developed into a more stabilized anastomosing channel system. The erosion of the old basalt bed significantly advanced and the configuration of new channels became more prominent. Semi-permanent isles started to emerge within the channel. The sinuosity gradually increased in order to dissipate the discharging force of river flow, and its velocity decreased (Rapp and Hill 1998). Point-bar deposits which contain basalt debris and angular coarse sands from the hillsides of the adjacent valleys were formed at the margin; the cross-sections of these deposits usually show well-stratified cross-bedding features.

10 For detailed opinions on information sharing practice among hominid individuals, see Mithen 1996. 
As the anastomosing system was laterally enlarged and the discharging capacity increase, the channel configuration developed into a meandering stream. Channel velocity decreased even more and the quantity of deposited sediments dramatically increased. The particle sizes of sediment were gradually reduced from sand to silt, and the discharging water hydrated and/or hydrolyzed the soluble minerals while the ionized chemical components were washed away. As a result, light-toned silt sediments were deposited over the cross-bedded sand layer. The time span of Phase 4 during which the sand and silt layers were deposited is from ca 120 to 60 kya based on the sequence of OSL dates, which can be correlated to the MIS 5e to the MIS 4.

\section{Phase 4}

ca 120- $60 \mathrm{kya}$

(MIS 5e-MIS 4)
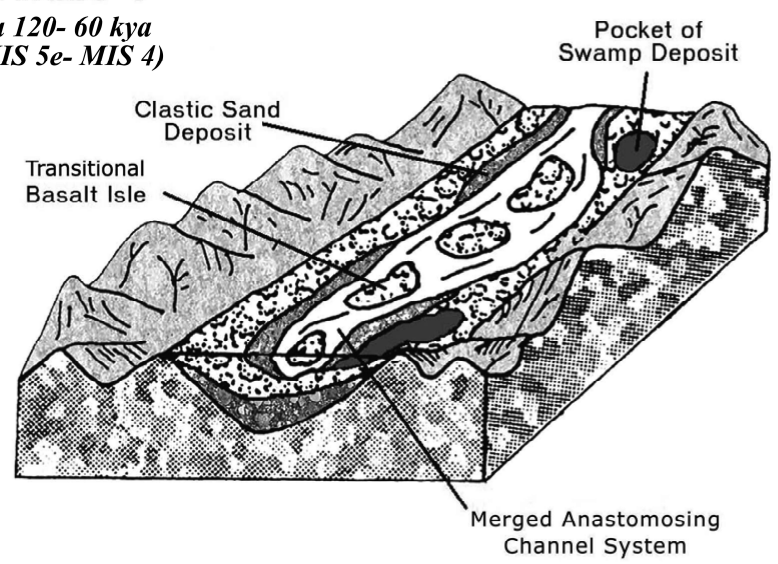

Figure 8. Illustration of Phase 4

Still, archaeological evidence is rarely found for this phase. Some artifacts have been discovered within the yellowish brown silt area at the Chŏngongni site (Bae 1988); but they are not believed to be in their original context since artifact concentrations were randomly distributed. The development of point-bar sediments and hydrated light-toned particles commonly indicate that the site area was located in close proximity to the 
frequently flooded riverside area and, therefore, the lithic artifacts would likelyhave been transported by the drainage wash-off. It is believed that hominids pursued the typical lifestyle of hunter-gatherers. Their provisioning would have been based on the accessibility of plant resources and small-game hunting or scavenging, all of which were based on the laborintensive foraging strategy. The existence of a local social network can be hypothesized. Following the complete termination of volcanic activity, accessible area in the landscape significantly increased and the primary territory for foraging activity became limited to the area below the ridge of hills since moving upland on an everyday-basis was not cost-effective in an "already-stabilized" environment (Yoo 1997). The hominid migration routes are expected to be centripetal toward some wide-open regions where a good view of the overall terrain could be ensured since such surveillance was a critical strategy for effective survival. Since the current terrain is generally identical to that of Phase 4, the Chŏngongni, Chuwŏlli, Kawŏlli, Kŭmp'ari and Changhŭngni sites might be considered as ideal residential areas due to the good accessibility to constant water resources and a rich woodland-based biomass.

Phase 5: the single channel down-cutting phase (ca 60- 20 kya)

As the meandering process was intensified, the discharging energy of the river channel decreased and the riverbanks gradually regressed. Under these less-turbulent depositional conditions, finer sediments were deposited in the overbank area. The river finally recovered its original level of discharging energy and the expanded magnitude of the river channel increased the down-cutting of the riverbed. Consequently, the riverbed was slowly lowered and the basalt bed became entirely exposed. As a result of a decreased flow speed, silt- and clay-dominant sediments were accumulated and some floodplains came to be highly populated beyond the riverbank.

The MIS 3 roughly corresponds to the Phase 5. While the temperature was slightly lower compared to Phase 4 (Yi 2000), the moderately mild 
climate accelerated the oxidization of the ferrous minerals in the sediment. With the approach of the dry and cold period around the terminal MIS 3, the wedge-shaped cracks developed and the AT tephras from Kyushu of the Japanese Archipelago were blown to the IHRA. A relatively mild temperature and stabilized floodplain would be the ideal condition for hominids to intensively occupy the IHRA; the tight distribution of archaeological horizons within the sediment and the rapid increase of site numbers imply that hominid occupation occurred within a relatively short-time span and the intensity of land use was accelerated until every suitable location was fully populated. The distance between sites became shorter, sufficient to make casual contacts occur frequently. Such frequent interaction promoted sharing and transferring of lithic technology. For example, the manufacture of the handaxe, which possibly originated as a result of this regular interaction to meet the common functional needs for sharing habitats within the same landscape, was widely propagated across the whole range of the IHRA. Accordingly, it is likely that its basic design elements were solidly "institutionalized" as hominid interrelationships strengthened and the frequency of producing handaxes increased. Its

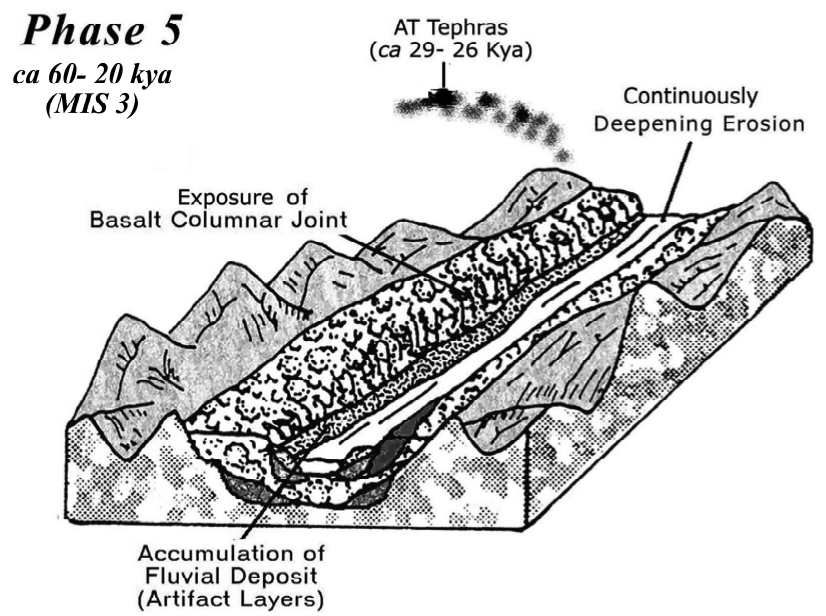

Figure 9. Illustration of Phase 5 
manufacturing techniques were imitated, socially learned from generation to generation, and finally established as a local tradition ( $\mathrm{McNabb}$ et al. 2004; Mithen 1996).

Even though lithic assemblage is generally dependent on the unique raw materials of the locale, similar tool types were prevalent across several locations. For example, the Chŏngongni hominids were dependent on crude quartz and quartzite and those of the Kawŏlli site predominantly used the medium-quality materials that were abundant within its territory, such as fine quartz. However, these two assemblages commonly include small tools such as sidescrapers, endscrapers, tranchets, notches, and so on, as well as sharing such stereotyped large tools as the chopper and the handaxe. In particular, these assemblages show clear inter-site variability in terms of the patterns by which flake blanks were transformed into intended tools. Both the Chŏngongni and Kawŏlli assemblages were basically dependent on their own unique blank reduction patterns; this "pattern-ization" is believed to reflect the change of the habitual practices of local hominids who shared a tendency for producing technological items assimilated to the constraints of raw material quality and availability.

Phase 6: the final stabilized phase (after ca 20 kya)

As the cold and dry MIS 2 approached, the sediment became weathered, transformed by such natural processes as dehydration, bioturbation and cryoturbation. The typical layer associated with the MIS 2 is the light grayish silty clay sediment filling and overlying the upper crack zone. Its structure and soil profile is different from normal fluvial sediments, and it was possibly formed by the accumulation of eolian dust blown by a strong continental air stream from the inland regions of China (Yi 2000). No artifacts have been discovered from this layer; but AT particles accumulated at the terminal MIS 3 have been frequently recovered. The layers above this upper crack zone are not well-preserved in this area. Most of them were disturbed by various forms of bioturbation (Bae 1988; Lim et al. 2005) and they were washed off by post-Pleistocene flooding. Alt- 
hough archaeological evidence is scarce, hominid occupation continued until the terminal Pleistocene. Based on the assumption (Yi 1999: 120) that the IHRA was like a "no man's land" during the MIS 2, it can be hypothesized that the overall biomass was seriously reduced and the adjacent floodplain area became sterile as the river water level lowered and the climate became cold and dry.

Except for the Changhŭngni and Hwadaeri site which yielded an exceptionally well-preserved Upper Palaeolithic assemblage above the AT horizon (Choi et al. 2001), only minimal quantities of Upper Palaeolithic artifacts have been discovered at several different sites. The procurement of plant resources was extremely limited and animal exploitation was hard to imagine, given the unsystematic lithic technology for effective hunting. Local population size possibly decreased and strategies for survival in extreme environmental conditions became indispensable. One solution to this stress was to change the quality of raw material by selecting technologically reliable micro-crystalline rocks. Most high-quality rocks available in this area are igneous metamorphic types such as obsidian, porphyry and vitrified quartz crystal. It is highly probable that their quarries were found in the vicinity of crater and the outcrops of intrusive plutonic rocks.

The systematic utilization of these high-quality raw materials became increasingly necessary. One of the pivotal technological solutions was to produce more refined tools. A sort of technological leap occurred, marked by the major shift of raw material selection. Associated with this shift was the intensification of modified small tools, which was itself an economizing strategy to increase the efficient use of high-quality raw material. As a result, the production of more intensively modified small tools and the economizing strategy of available high-quality material were eventually practiced among hominids. This shift in raw material quality, a hallmark of the Upper Palaeolithic, would have promoted several corresponding activities such as scheduled migration and more patterned land-use (see Barton et al. 2004; Cowans 1999; Kuhn 1991, 1992; Mellars 1989). The maximum range of hominid mobility would have greatly increased and 


\section{Phase 6}

\section{After ca 20 kya (since MIS 2)}

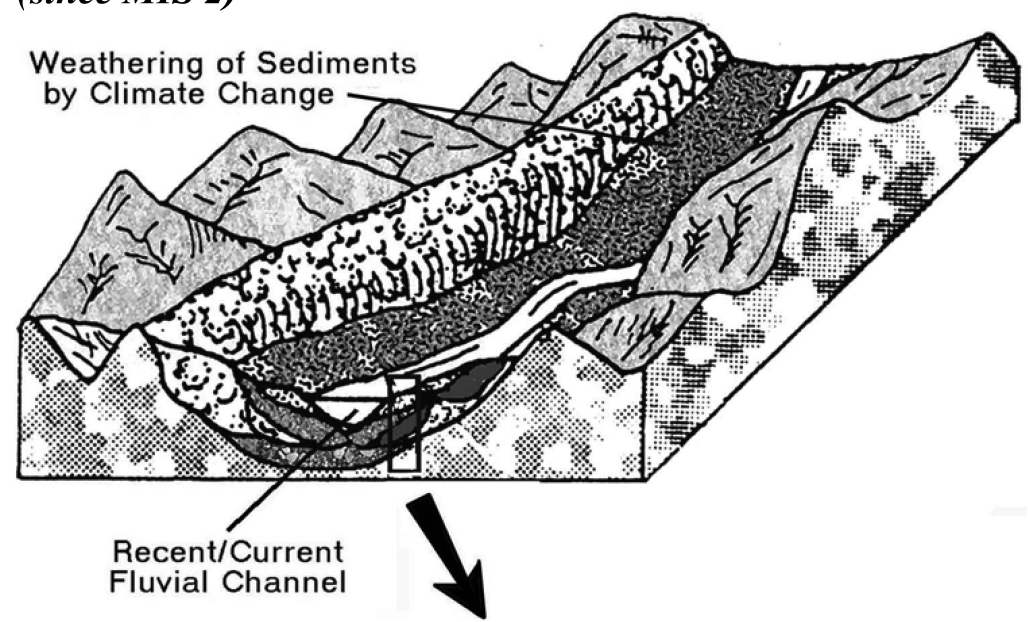

Post-Depositional Transformation Phase (Disturbed artifacts)

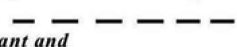

Weathering-dominant and Climate Fluctuation Phase

(Intensive hominid occupation)

Recovered Fluvial Channel and Deposition-dominant Phase

(Rare evidence of hominid occupation)

Rejuvenating Fluvial Channel

and Erosion-dominant Phase

(Occasionally observable stratigraphic units)

Volcanic Activity Phase

(More than one lava flow)
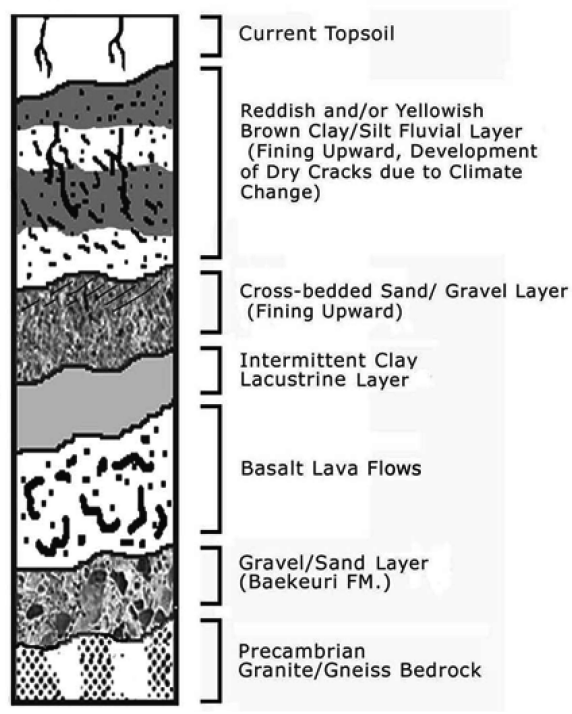

Figure 10. Illustration of Phase 6 and currently observed stratigraphic correlation

Pre-Volcanic Eruption Phase

(Consolidated rocks and partially cemented river terrace deposits)

Brown Clay/Silt Fluvial Layer (Fining Upward, Development of Dry Cracks due to Climate Change)

Cross-bedded Sand/ Gravel Layer ining Upward)

Intermittent Clay

Basalt Lava Flows

Gravel/Sand Layer

recambrian

Granite/Gneiss Bedrock 
mutual cooperation and/or conflict would probably have emerged in order to cope with the competition that greater mobility stimulated.

The area of ideal habitats was largely limited to small patchy spots, most of which tended to be located adjacent to available quarries. As a result, the site distribution pattern changed from being "uniform and sparse" to "clustered and dense." No evidence of systematic animal resource utilization has been recovered thus far. The lithic technology, as represented by the Hwadaeri and Changhŭngni assemblages, was based on the availability of high-quality raw material, but the acceptance of highly systematic technological components such as the prismatic core and blade technique has not been well-demonstrated. Compared to the preceding assemblages, the sizes of retouched pieces are significantly smaller, implicating the practice of a strict economizing strategy of raw material utilization.

\section{Conclusion}

Narrating people's history in ancient times is like romanticizing the past with a handful of data. Especially, archaeologists who always face a lack of positivistic written records can only rely on material data which never reveal anything specific about the human past. This inherent impediment has caused a bias toward the mere description of artifact variability hovering within the axis of time and space; a subtle term "culture" is usually employed to integrate the characteristics of artifacts and its relevance to human interaction with no reference to human motivation and environmental contingency. This article is an example of an attempt to expand the scope of archaeological interpretation from a historical perspective. Although the data itself is not directly associated with human agency, we have observed that a combination of naturalistic evidence (i.e. geological records, chronometric dates) and archaeological remains (i.e. lithic assemblages) lead to a meaningful depiction of Palaeolithic hominid's evolutionary strategy within a specific landscape (the IHRA). This was 
made possible by clarifying the resolution of time-scale and the explicability of environmental change.

Based simply on the observable archaeological data and the current chronological framework, it can be concluded that the evolution of lithic technology and the history of human occupation in the IHRA occurred at the same tempo as the evolving Pleistocene environment. The relatively warm and mild conditions before the MIS 3 were correlated with a nonschematic and poorly conceptualized technology. This technology developed with actions of hominids in accordance with changes in the river channel system. Hominids were able to selectively assimilate to the changes in their surroundings; they survived such catastrophic disasters as the volcanic eruption in the entire channel area but successfully responded to the transformation of terrains and resource availability and they spontaneously created some stylistically unique tools like handaxe.

This routine continued for a quite a long time until the "stressful" conditions of the MIS 2 necessitated a prompt technological response; this technology is marked by an abrupt change in the quality of raw material associated with an equally rapid development of highly operational small tools like microblades. However, the dynamics of the emergence of Upper Palaeolithic in the IHRA are yet to be elucidated since data isl imited and fragmentary. Detailed chronological framework for delineating lithic technological evolution is still at the level of speculation. More relevant archaeological and geological data must be accumulated and appropriate analytical research tools created to sufficiently examine this issue.

\section{Reference}

1. Bae, Kidong. "The Significance of the Chôngongni Stone Industry in the Tradition of the Palaeolithic Culture in East Asia." PhD Dissertation. University of California. Berkeley, 1988.

2. Bae, Kidong, G. Yoon, H., Lee, S., Hwang, and Y. Kim. Report of Excavation of the Keumpari Site. Institute of Cultural Properties 
in Hanyang University, Ansan (in Korean), 2006.

3. Bae, K., S. Ahn, H. Lee, B. Chun, and C. Lee. The excavation report of the Hoengsanri Site. Institute of Cultural Properties in Hanyang University, Ansan (in Korean), 2006.

4. Barton, C. M., J. Bernabeu, J. E. Aura, O. Garcia, S. Schmich, L. Molina. "Long-term socioecology and contingent landscapes." Journal of Archaeological Method and Theory, 11(2004): 253- 94.

5. Braudel, F. The Mediterranean and the Mediterranean World in the Age of Philip II (vol. 1). New York: Harper and Row, 1972.

6. Ibid, "History and the social sciences: the longue durée," in On History, 25-54. Chicago: University of Chicago Press, 1980.

7. Brown, A. C. Alluvial geoarchaeology- Floodplain Archaeology and Environmental Change. Cambridge: University Press, 1997.

8. Butzer, K. W. Archaeology as Human Ecology: Method and Theory for a Contextual Approach. Cambridge: University Press, 1982.

9. Chazan, M. "Conceptions of time and the development of Paleolithic chronology." American Anthropologist 97(1995): 457- 67.

10. Choi, Bok-kyu., S. Choi, S. Choi, H. Lee, and J. Cha. The Janghung-ri Palaeolithic Site. Institute of Kangwon Archaeology. Chuncheon (In Korean), 2001.

11. Choi, Bok-kyu., and H. Yoo. The Hwadae-ri Shimteo Palaeolithic Site. Pocheon City, Korea, Institute of Kangwon Archaeology, Chuncheon (In Korean), 2006.

12. Cowans, F. L. "Making sense of flake scatters: lithic technological strategies and mobility." American Antiquity 64(1999): 593- 607.

13. Gilman, A. "Explaining the Upper Palaeolithic Revolution," In Marxist Perspectives in Archaeology, edited by M. Spriggs, 11526. Cambridge: Cambridge University Press, 1984.

14. Fletcher, R. "Time perspectivism, Annales, and the potential of archaeology," in Archaeology, Annales and Ethnohistory, edited by A. Bernard Knapp, 35- 49. Cambridge: Cambridge Univ. Press, 1992.

15. Gamble, C. Timewalkers: the Prehistory of Global Colonization. 
Cambridge: Harvard University Press, 1993.

16. Ibid, "Palaeolithic society and the release from proximity: a network approach to intimate relations." World Archaeology 29(1998): 426- 49.

17. Ibid, The Palaeolithic Societies of Europe. Cambridge: Cambridge University Press, 1999.

18. Ibid, "Social Archaeology and the Unfinished Business of the Paleolithic," in Explaining Social Change: studies in Honour of Colin Renfrew edited by J. Cherry, C. Scarre, and S. Shennan, 726. Cambridge: McDonald Institute for Archaeological Research, 2004.

19. Gamble, C. and M. Porr. "From empty spaces to lived lives: Exploring the individual in the Palaeolithic," in The Hominid Individual in Context: Archaeological Investigations of Lower and Middle Palaeolithic Landscapes, Locales and Artifacts edited by C. Gamble and M. Porr, 1- 12. London: Routledge, 2005.

20. Gao, X. and C. J. Norton. "A critique of the Chinese 'Middle Palaeolithic." 'Antiquity 76 (2001): 397- 412.

21. Giddens, A. The Constitution of Society- Outline of the Theory of Structuration. Cambridge: Polity Press, 1984.

22. Hodder, I. "The contribution of the long term." In Archaeology as Long-Term History, edited by I. Hodder, 1-8. Cambridge: Cambridge University Press, 1987.

23. Ibid. "Creative thought: a long-term perspective." In Creativity in Human Evolution and Prehistory, edited by S. Mithen, 61- 77. London: Routledge, 1988.

24. Hopkinson, T., and M. J. White. "The Acheulian and the handaxe: structure and agency in the Palaeolithic." In The Hominid Individual in Context: Archaeological Investigations of Lower and Middle Palaeolithic Landscapes, Locales and Artifacts, edited by C. Gamble and M. Porr, 13- 28. London: Routledge, 2005.

25. Kim, Kyu Han and H. Lee. "Geochemistry and K-Ar age of Gabbroic rocks in the Konamsan area of Yeonchon Province, South 
Korea." Economic Environmental Geology of Korea 27(1994): $27-$ 39.

26. Kim, Wonyong and Y. Chung. "Preliminary report on the Chôngongni Acheulian Industry." Jindan Review of History (Jin Dan Hak Bo) 46/47(1979): 7-47.

27. Klein, R. "Fully modern humans." In Archaeology at the Millennium, edited by G. M. Feinman, and T. D. Price, 109- 135. New York: Kluwer Academic/Plenum Publishers, 2001.

28. Knapp, A. B. "Archaeology and Annales : time, space and change." In Archaeology, Annales and Ethnohistory, edited by A. Bernard Knapp, 1-21. Cambridge: Cambridge Univ. Press, 1992.

29. Knapp, A. B., and W. Ashmore. "Archaeological Landscapes: Constructed, Conceptualized, Ideational." In Archaeologies of Landscape, edited by W. Ashmore and A. B. Knapp. 1- 31. Malden: Blackwell, Malden, 1999.

30. Kuhn, S. L. "Unpacking reduction: lithic raw-material economy in the Mousterian of West-Central Italy." Journal of Anthropological Archaeology 10 (1991): 76- 106.

31. Ibid. "On planning and curated technologies in the Middle Paleolithic.” Journal of Anthropological Research 48 (1992): 185- 214.

32. Lim, Hyoun-Soo, Y. Lee, and S. Yi. "A preliminary study of large burrows at Jeongok and Naju palaeolithic sites, Korea." Journal of Geological Society of Korea 40 (2004): 559- 66.

33. McNabb, J., F. Binyon, and L. Hazelwood. "The Large Cutting Tools from the South African Acheulian and the Question of Social Traditions." Current Anthropology 45 (2004): 653- 77.

34. Mellars, P. "Major issues in the emergence of modern humans." Current Anthropology 30 (1989): 349- 85.

35. Mithen, S. Thoughtful Foragers. Cambridge: Cambridge University Press, 1990.

36. Ibid. "Social learning and cultural tradition." In The Archaeology of Human Ancestry: Power, Sex and Tradition, edited by J. Steele and S. Shennan, 207- 229. London: Routledge, 1996. 
37. Movius, H. L. Jr. "Early Man and Pleistocene Stratigraphy in Southern and Eastern Asia." Papers of the Peabody Museum of American Archaeology and Ethnology, vol. 19(5), Harvard University, Cambridge, 1944.

38. Naruse, T. "Loess-paleosol sequence in the Chôngongni palaeolithic site." In Geological Formation of the Chôngongni Palaeolithic Site and Palaeolithic Archaeology in East Asia. edited by Kidong Bae et al., 143- 56. Yeonchon: Yeoncheon County and the Institute of Cultural Properties of Hanyang University, 2003.

39. Norton, C. J., K. Bae, J. Harris, and H. Lee. "Middle Pleistocene handaxes from the Korean Peninsula." Journal of Human Evolution 51 (2006): 527- 36.

40. Rapp, G. Jr. and C. Hill. Geoarchaeology- The Earth-Science Approach to Archaeological Interpretation. New Haven: Yale University Press, 1998.

41. Smith, M. E. "Braudel's temporal rhythms and chronology theory in archaeology." In Archaeology, Annales and Ethnohistory, edited by A. Bernard Knapp, 23- 49. Cambridge: Cambridge Univ. Press, 1992.

42. Vandenburgh, J. "Timescales, climate and river development." Quaternary Science Reviews 14 (1995): 631- 8.

43. Yi, Seonbok. "Chronostratigraphy of Palaeolithic occurrences in the Imjin Basin." Journal of the Korean Archaeological Society 34 (1996): 135- 60. (In Korean)

44. Ibid. "The temporal change of Korean Palaeolithic industry." In Proceedings of Symposium to Commemorate the 80th Birthday Celebrations of Professor Chosuke Serizawa-World Views on the Early and Middle Paleolithic in Japan, 115- 120. Sendai: Sendai Fukushi University, 1999.

45. Ibid. "For chronology and stratigraphy of Korean Palaeolithic." Journal of the Korean Archaeological Society 42 (2000): 1-22. (In Korean with English summary)

46. Ibid. Jangsan-ri: A Lower Palaeolithic Site in Paju, Korea. Seoul: 
Seoul National University Museum, 2004. (In Korean)

47. Ibid. "New Data on the formation of the basalt plain in the Imjin River Basin." Journal of the Geomorphological Association of Korea 12 (2005): 21- 38. (In Korean)

48. Yi, Seonbok, Y. Lee, and J. Kim. "The Changsanni Terrace and lava deposit in the upstream area of the Imjin River." Journal of the Geomorphological Association of Korea 11(2004): 1-14.

49. Yi, Seonbok, Y. Yoo, D. Kim. Excavation Report at Chôngongni (aka Jeongok ACF) Site and its Vicinity. Seoul: Seoul National University Museum and Jeongok Agricultural Cooperative Federation, 2006.

50. Yoo, Yongwook. "On the characteristics of Handaxes from ImjinHantan Riverine Area." Journal of the Korean Archaeological Society 36 (1997): 147-80. (In Korean with English Abstract)

51. Ibid. Beyond the Movius Line: Hominin Occupation and Technological Evolution in the Imjin-Hantan River Area, Korea. Oxford: British Archaeological Report International Series 1772, J. E. Hedges, 2008. 
$\langle$ Abstract〉

\section{Narrating Palaeolithic Human Settlement History \\ : the case of the Imjin-Hantan River Area, Korea}

Yongwook Yoo

This article intends to furnish a narrative story-telling with the broad perspective on the human past rather than simply depending on the analytical examination of archaeological data. For the purpose of this task, Ferdinand Braudel's concept of "la longue durée" is applied to parallel the environmental background and hominid's life/land-use patterns based on the geological data and archaeological remains. The Imjin-Hantan River Area (IHRA), known for the discovery of Acheulian-like handaxe, was occupied from ca 0.23 mya to the final Pleistocene; the hominids continuously changed their residing patterns in the landscape with actively modifying the lithic technological organization as a response to the environmental change. Integrating the geological features, absolute dates and characteristics of lithic assemblages from individual sites, we can recognize six phases of environmental changes based on the development of river channel system. These six phases witness different patterns of hominid's adaptation in this area and correspondingly yield different mode of raw material utilization and lithic procurement. While more accurate geological dates are yet to be published and the description of lithic assemblages may be changed by new data, it is prospecting that Braudel's la longue durée is a useful concept for meaningfully narrating a long-term human occupation history in the discipline of prehistoric archaeology.

Keywords: narrative, the IHRA, Acheulian, la longue durée, river channel system 
〈국문초록〉

\section{舊石器 時代 古人類 占據史의 敍事 \\ - 韓國 臨津-漢灘江 流域手 事例 -}

유용욱 (충남대학교 인문대학 고고학과)

본 고는 구석기 시대 고인류의 거주 지역 내 자원 활용과 점거 활동에 대한 고고학 자료의 단순 분석 고찰에서 벗어나, 보다 큰 의미로서 고인류의 과거에 대한 폭 넓은 이해를 도모하기 위해 서사 구조의 틀을 마련하였다. 이러한 작업 의 일환으로서 브로델의 '장기지속' 개념을 도입하여, 한국 임진-한탄강 유역 지 질학 자료에 반영 된 구석기 시대 환경 변화 과정을 고인류의 생계 경제 및 공 간 활용 양상의 변동과 대비시켰다. 임진-한탄강 유역은 아슐리안형 주먹도끼가 다수 발견된 구석기 유적군으로서, 약 23만년전부터 홍적세 최말기까지 지속적 으로 인구가 거주해 왔으며, 이러한 고인류들은 환경의 변화에 따라 각기 다른 점거 양상을 보이면서 능동적으로 석기 기술 조직을 변동 시키면서 경관 내에서 거주해 왔다. 지역 내에서 얻어진 지질학적 양상과 절대 연대 자료 및 해당 유적 들의 석기군 특성을 종합한 결과, 이 지역은 하계망의 변천에 따라 크게 6단계의 지형 발달 단계로 구분할 수 있다. 그리고 이러한 6단계는 상호 각기 다른 방식 으로 고인류의 적응 과정을 초래하였고, 그들이 사용한 석재 및 제작한 석기군의 양상도 이에 수반하는 양상을 보여주고 있다. 지질학적 층서 단위의 연대치는 차 후 보다 정교한 결과를 기대할 수 있고 석기군의 특성도 보다 새로운 자료에 의 해 다른 견해가 제시되겠지만, 브로델의 장기지속 개념은 장기간에 걸친 인류 점 거사를 다루는 선사 고고학 연구에서도 의미 있는 서사를 제공할 수 있는 것으 로 드러났다.

주제어: 서사, 임진-한탄강 유역, 아슐리안, 장기지속, 하계망 